\title{
Phthalocyanines and Metal Phthalocyanines with Phosphoryl Groups: Supramolecular Ensembles, Photochemical and Photobiological Properties
}

\author{
Polina A. Mikhina ${ }^{\mathrm{a}, \mathrm{b}}$ Denis V. Mishchenko, ${ }^{\mathrm{a}, \mathrm{c}}$ Mariya A. Lapshina $^{\mathrm{a}}$ \\ Pavel A. Tarakanov, ${ }^{\mathrm{a}, \mathrm{d} @ 1}$ Vladimir E. Baulin, ${ }^{\mathrm{d}}$ and Nataliya F. Goldshleger ${ }^{\mathrm{a} @ 2}$ \\ anstitute of Problems of Chemical Physics RAS, 142432 Chernogolovka, Russia \\ ${ }^{\mathrm{b}}$ Lomonosov Moscow State University, 119991 Moscow, Russia \\ 'Scientific and Educational Center of Moscow State Regional University in Chernogolovka, 141014 Mytishchi, Russia \\ 'Institute of Physiologically Active Compounds RAS, 1142432 Chernogolovka, Russia \\ ${ }^{\circledR 1}$ Corresponding author E-mail: pavel369@inbox.ru \\ ${ }^{\circledR 2}$ Corresponding author E-mail: nfgold@icp.ac.ru
}

\begin{abstract}
Based on the supramolecular approach, the conditions for the solubilization and disaggregation of phosphoryl-containing phthalocyanines and their metal complexes (I-IV) in the aqueous environment due to the formation of supramolecular ensembles are found. For the first time, zinc phthalocyaninate with phosphoryl-containing groups in the macrocycle (IV) was studied as a potential photosensitizer in various media. The supramolecular organization of Ps in solution, the singlet oxygen quantum yield $\Phi_{\Delta}{ }^{I V}$ in DMSO $(0.48 \pm 0.05)$ and an organized microheterogeneous medium based on cationic cetyltriphenylphosphonium bromide $(0.54 \pm 0,05)$ in combination with low cytotoxicity, sufficiently high phototoxicity $\left(I_{50}\right.$ dose) and the formation of intracellular reactive oxygen species in vitro upon irradiation allow one to consider phosphoryl-containing phthalo- and metallophthalocyanines as deserving of attention and further research as compounds useful for PDT.
\end{abstract}

Keywords: Phthalocyanines, supramolecular ensembles, cetyltriphenylphosphonium bromide, cetyltrimethylammonium bromide, sodium deoxycholate, singlet oxygen, quantum yield, phototoxicity, reactive oxygen species, fluorescent microscopy.

\section{Фталоцианины и металхофталоцианины с фосфорильными группами: супрамолекулярные ансамбли, фотохимические и фотобиологические свойства}

\author{
П. А. Михина, ${ }^{\mathrm{a}, \mathrm{b}}$ А. В. Мищенко, ${ }^{\mathrm{a}, \mathrm{c}}$ М. А. Аапшина, ${ }^{\mathrm{a}}$ П. А. Тараканов, ${ }_{1}^{\mathrm{a}, \mathrm{d} @ 1}$ \\ В. Е. Баулин, ${ }^{d}$ Н. Ф. Гольдшлегер ${ }^{\text {a@2 }}$

 \\ ${ }^{\mathrm{b}}$ Московский государственный университет имени М.В. Ломоносова, 119991 Москва, Россия \\ 'Научно-образовательный центр в г. Черноголовка Московского государственного областного университета, \\ 141014 Мытищи, Россия \\ ${ }^{\mathrm{d}}$ Институт физиологически активных вещчеств РАН, 142432 Черноголовка, Россия \\ ${ }^{\circledR 1}$ E-mail: pavel369@inbox.ru \\ @2E-mail:nfgold@icp.ac.ru
}

На основе супрамолекулярного подхода найдень условия солюбилизащии и дезагрегаџии фосфорилсодержащих фталоциианинов и их металлокомплексов в водной среде благодаря образованию супрамолекулярных ансамблей. Впервые фталочианинат ичинка с фосфорил-содержащими группами в заместителях макроцикла был изучен как потенциальный ФС в различных средах. Супрамолекулярная организация ФЦ в растворе, квантовый выход 
синглетного кислорода $\Phi_{\Delta}{ }^{I V}$ в ДМСО и организованной микрогетерогенной среде на основе катионного цетилтрифенилфосфоний бромида в сочетании с низкой циитотоксичностью, достаточно высокой фототоксичностью (доза $\left.I C_{50}\right)$ и образованием внутриклеточных активных форм кислорода іп vitro при облучении позволяют рассматривать фосфорилсодержащце фтало- и металлофталоциианины как заслуживающие внимания и дальнейшего исследования в качестве соединений, полезных для ФДТ.

Ключевые слова: Фталоцианины, супрамолекулярные ансамбли, цетилтрифенилфосфоний бромид, цетилтриметиламмоний бромид, дезоксихолат натрия, синглетный кислород, квантовый выход, фототоксичность, активные формы кислорода, флуоресцентная микроскопия.

\section{Introduction}

Phthalocyanines (Pcs) and their supramolecular aggregates find application in molecular electronic devices and chemical sensors, catalysis, biology and medicine including photodynamic therapy (PDT). ${ }^{[1,2]}$ The PDT method involves three non-toxic components, namely, photosensitizer (PS), light and oxygen. PS accumulates in the tumor. When irradiated with light with a wavelength close to the maximum of its absorption band, with the participation of the triplet state of the PS reactive oxygen species (ROS) are generated, including singlet oxygen $\left({ }^{1} \mathrm{O}_{2}\right)$. They have a cytotoxic effect on tumor cells (Scheme 1) leading to tumor destruction. ${ }^{[3]}$

The main requirements to an ideal PS are the following:

1. Thoroughly characterized and available individual compounds; stability upon storage and use; low cytotoxicity; selectivity in respect of tumor cells; fast excretion.

2. Intense maximum in the visible and NIR ranges of electromagnetic spectrum $(650-850 \mathrm{~nm})$; intense fluorescence allowing diagnostics.

3. The lifetime of the triplet state, sufficient for the realization of the photodynamic effect; excitation energy not less than $94 \mathrm{~kJ} / \mathrm{mol}$ necessary for the formation of ${ }^{1} \mathrm{O}_{2}$.

Such properties of Pcs as chemical stability, absorption spectrum with the maximum $\left(\varepsilon \geq 10^{5} \mathrm{M}^{-1} \cdot \mathrm{cm}^{-1}\right)$ in the above mentioned range, low toxicity and others allow them to be considered as potential PS in fluorescent diagnostics and PDT of tumors. ${ }^{[4,5]}$ Photophysicochemical properties of diamagnetic non-transition metal (Al, Ga, $\mathrm{Zn}$ and others) phthalocyaninates quite well meet the requirements of PDT and fluorescent diagnostics. ${ }^{[6,7]}$

Generation of ROS (mainly ${ }^{1} \mathrm{O}_{2}$ ) requires the presence of phthalocyanine as a monomer and the absence of aggregation in physiological conditions. The presence of aggregates (mainly of $H$-type) decreases quantum yield of luminescence and lifetime of excited states. ${ }^{[8]}$ As a result, the formation of ${ }^{1} \mathrm{O}_{2}$ and other reactive species responsible for cell death is inhibited. ${ }^{[9]}$ Quantum yield of singlet oxygen and photostability of PS in oxidation conditions are important parameters for PDT. At the same time, high photostability of Pcs can be both advantage and shortcoming.

One of possibilities of preventing aggregation of Pcs in aqueous medium is the use of surfactants of various types to provide an environment for Pcs compatible with biological medium. For example, review ${ }^{[10]}$ was devoted to supramolecular interactions in redox transformations of an electroactive component (fullerene and its derivatives, transition metal complexes and metallophthalocyanines) embedded in an artificial lipid matrix, and their role in an aqueous medium.

This paper reports on the study of supramolecular organization of Pcs and $\mathrm{Zn}$ phthalocyaninate with substituents in the macrocycle bearing dioxyphosphoryl and oxy(alkoxy)



Scheme 1. Photodynamic action scheme. 
A

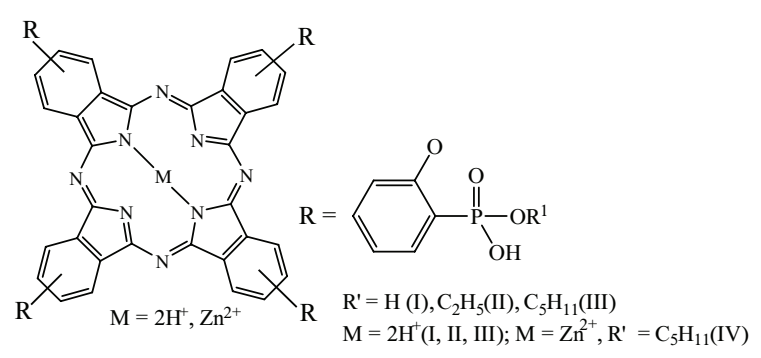

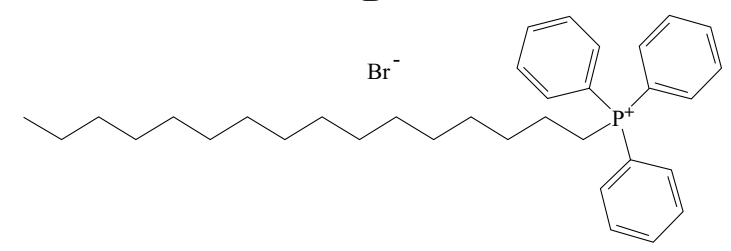

Cetyltriphenylphoshonium bromide (CTPB)

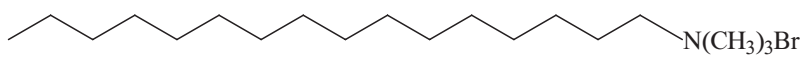

Cetyltrimethylammonium bromide (CTAB)
$\mathrm{C}$

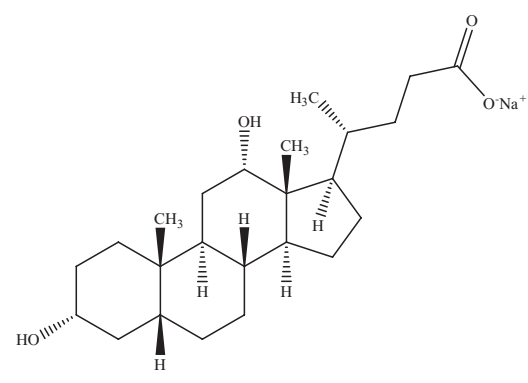

Sodium deoxycholate (SDC)

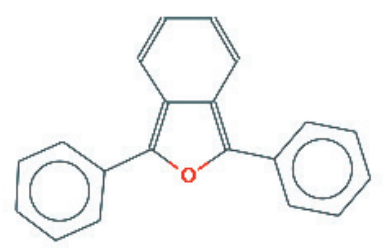

1,3-Diphenylisobensofuran (DPBF)

$\mathrm{D}$

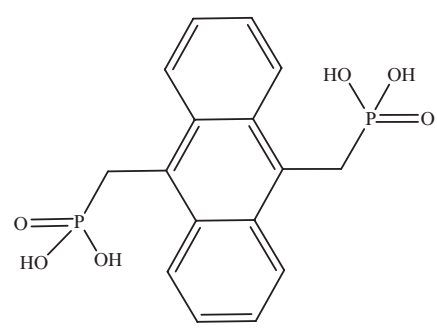

9,10-Bis(dihydroxyphosphinylmethyl)anthracene $\left(\right.$ Anth $\left._{2}\right)$

Figure 1. Structures of phthalocyanines and zinc phthalocyaninate with phosphonate and mono(alkyl)phosphonate substituents in the macrocycle (A), cationic CTPB and CTAB (B), anionic sodium deoxycholate (C), 1,3-diphenylisobenzofuran and 9,10-bis(dihydrox yphosphinylmethyl)anthracene (D).

phosphoryl groups in phosphate buffer and surfactant solutions, and their some properties. Photochemical properties of zinc phthalocyaninate were also analyzed in the presence of singlet oxygen quenchers, namely, 1,3-diphenylisobenzofuran (DPBF) and 9,10-bis(dihydroxyphosphinylmethyl) anthracene $\left(\right.$ Anth $\left._{2}\right)$ for DMSO and microheterogeneous aqueous medium based on cationic surfactants - cetyltriphenylphosphonium bromide (CTPB) and cetyltrimethylammonium bromide CTAB), respectively. The structures of Pcs, surfactants and chemical traps for singlet oxygen are presented in Figure 1.

\section{Experimental}

\section{General}

Tetraphosphonic and tetra(monoalkyl)phosphonic acids of phthalocyanines (I, II, and III), and tetra(monoamyl)phosphonic acid of zinc phthalocyaninate (IV) were obtained as described in. ${ }^{[11]}$ 9,10-Bis(dihydroxyphosphinylmethyl)anthracene was prepared according to procedure. ${ }^{[12]}$ Sodium deoxycholate (Aldrich, $98 \%$ ), 1,3-diphenylisobenzofuran (Aldrich, $97 \%$ ), cetyltriphenylphosphonium bromide and cetyltrimethylammonium bromide (Merck, $98 \%)$ were used as received. 3-(4,5-Dimethyl-2-thiazolyl)-2,5-diphenyl- $2 \mathrm{H}$-tetrazolium bromide (Sigma-Aldrich) and $\mathrm{DCFH}_{2}-\mathrm{DA}$ were purchased from Sigma-Aldrich. Solutions were prepared in bidistilled water. All reagents necessary for preparation of phosphate buffer $(\mathrm{p} H=7.4)$ were extra-pure grade.
Samples of I-IV were added to known volume of phosphate buffer (PBS) and centrifuged after full dissolution. In spectral measurements, samples of surfactants of known concentration were placed in a cell filled with Pc solution. Measurements were carried out to constant value of optical density. The samples were protected from light.

\section{Procedure for Analysis of Phosphoryl Containing Zn Phthalocyaninate as PS}

1,3-Diphenylisobenzofuran and 9,10-bis(dihydroxyphosphin ylmethyl)anthracene were used as singlet oxygen quenchers for DMSO and microheterogeneous medium of cationic surfactant. Freshly prepared solution comprising PS, quencher and solvent was used in each experiment. Cationic cetyltrimethylammonium bromide or cetyltriphenylphosphonium bromide in phosphate buffer were used for the water-PS system. Concentration of IV in DMSO and phosphate buffer was $\mathrm{X} \cdot 10^{-6} \mathrm{M}$, where $\mathrm{X}$ was from 1 to 10 , and concentration of Anth $\mathrm{X}_{2}$ in phosphate buffer was $\mathrm{X} \cdot 10^{-5}$ $\mathrm{M}$, where $\mathrm{X}$ was from 1 to 10 . Concentration of the quencher was equal or lower than $10 \cdot 10^{-5} \mathrm{M}$ to avoid chain reaction of oxidation of DPBF in the presence of oxygen. The measurements were carried out in a $1.0 \mathrm{~cm}$ cuvette, and for aqueous system, a 96 -well plate $(200 \mu \mathrm{L}$ well capacity) was used, that allowed us to simultaneously study a series of solutions. Absorption spectra for quencher and PS in time were recorded with a Cary $60 \mathrm{UV}-\mathrm{Vis}$ spectrophotometer (Agilent Technologies Bayan Lepas Free, Malaysia) equipped with an interface for computer recording of spectra and thermostated cell holder, and with a multi-functional TECAN SPARK 10M spectrophotometer (Tecan, Switzerland) 
in the dark at $24.3^{\circ} \mathrm{C}$. Solutions under study were irradiated with an ALKhT-ELOMED laser apparatus (Russia) ( $\lambda=670 \mathrm{~nm}$, optical radiation power equal to $0.3 \mathrm{~W}$ ) in continuous mode by pulses of 1 to 50 seconds duration.

Quantum yield of singlet oxygen in DMSO or aqueous microheterogeneous medium of cationic surfactant (in the air, no additional oxygen treatment) was determined by a comparison method ${ }^{[13]}$ and calculated according to:

$$
\Phi_{\Delta}^{\mathrm{i}}=\Phi_{\Delta}^{\mathrm{ref}} \frac{K^{\mathrm{i}} \cdot I_{\mathrm{abs}}^{\mathrm{ref}}}{K^{\mathrm{ref}} \cdot I_{\mathrm{abs}}^{\mathrm{ref}}},
$$

where $K^{\mathrm{i}}$ and $K^{\mathrm{ref}}$ are reaction rate constants for photobleaching of 1,3-diphenylisobenzofuran or 9,10-bis(dihydroxyphosphinyl methyl)anthracene under laser irradiation in the presence of PS and reference compound; $I_{\mathrm{abs}}=I_{0}(\lambda) \cdot\left(1-10^{-A(\lambda)}\right)$, where $I_{0}$ is laser radiation intensity at corresponding wavelength, and $A(\lambda)$ is optical density of studied macrocycle at corresponding wavelength. The value of $\Phi^{\text {ref }}$ for PcZn used as a reference compound was 0.67 in DMSO, ${ }^{[14]}$ and $\Phi_{\Delta}{ }^{\mathrm{MB}}$ for MB in water $\left(\mathrm{p} H\right.$ 7.4) was $0.39 .^{[15]} K^{\mathrm{i}}$ and $K^{\text {ref }}$ were determined from the first-order kinetics equation linearized as $\ln C=\ln C_{0}-k \cdot \tau$, where reaction rate constant was calculated as a slope of linear function to time axis: $-\operatorname{tg} \alpha=k$. Concentration of 1,3-diphenylisobenzofuran and 9,10-bis(dihydro xyphosphinylmethyl)anthracene $\left(C_{\mathrm{i}}\right)$ was found from the BouguerLambert-Beer law: $A(\lambda)=\varepsilon(\lambda) \cdot l \cdot C$, where $A(\lambda)$ is optical density; $\varepsilon(\lambda)$ is molar absorption coefficient; $l$ is solvent layer thickness, and $C$ is concentration of dissolved compound.

Fluorescence spectra for solutions of III and III/CTAB in phosphate buffer, and IV in micellar SDC solution were measured with a PerkinElmer LS55 spectrofluorimeter in $10 \mathrm{~mm}$ quartz cells in the air at room temperature. The slit width was $10 \mathrm{~nm}$ and detection angle was $90^{\circ}$. For III, excitation spectra were recorded at $\lambda_{\mathrm{em}}=710 \mathrm{~nm}$, and emission spectra were recorded at $\lambda_{\text {ex }}=650 \mathrm{~nm}$. For $\mathbf{I V}$, excitation spectra were recorded at $\lambda_{\text {em }}=725$ and emission spectra were recorded at $\lambda_{\text {ex }}=620 \mathrm{~nm}$. Position and shape of the emission band are not dependent on exciting light wavelength $(578,614,650$ and $675 \mathrm{~nm})$. The bands which can be attributed to light scattering on microheterogeneous medium particles were not found upon excitation of III by light with wavelengths lying in the above mentioned range. ${ }^{[16,17]}$ No fluorescence was observed for all background solutions. The absorption spectra before and after the fluorescence measurements remained unchanged, that is, Pc did not decompose during photoexcitation in the spectrofluorimeter.

Spectrophotometric measurements were carried out with a Specord plus (Analytikjena, Germany) and a Specord M-40 spectrophotometer in 1,2 and $10 \mathrm{~mm}$ quartz cells at room temperature. In some cases absorption spectra were deconvoluted into Gaussian components using Origin package.

\section{Biological Experiment}

Cell culture. Experiments were performed on HeLa cells (human cervix adenocarcinoma) received from the collection of vertebrata cell cultures (Saint Petersburg, Russia). The tumor cells were grown in EMEM medium (PanEco, Russia) containing $10 \%$ embrionic whey (Biowest, France), penicillin (50 units $/ \mathrm{mL}$ ), and streptomycin $(50 \mathrm{mg} / \mathrm{mL})$ at $37^{\circ} \mathrm{C}$ in $5 \% \mathrm{CO}_{2}$ atmosphere.

Procedure for deteremination of cytotoxicity and photoinduced cytotoxicity is reported in. ${ }^{[18]}$ Cell viability was determined as a percentage of MTT staining of control (untreated) cells. $\mathrm{IC}_{50}$ dose was calculated using MS Excel and Origin program packages. $\mathrm{IC}_{50}$ dose was calculated using the analysis of median effect. ${ }^{[19-21]}$

Determination of intracell content of $\mathrm{ROS}$ with $\mathrm{DCFH}_{2}-\mathrm{DA}$ as detector in photoinduction conditions. Cells were sown in 96 well cultural plates with $25 \cdot 10^{3} / 100 \mathrm{~mL}$ cells per well. Compound IV in PBS was added to incubation medium at final concentration ranging from 0.195 to $100 \mathrm{mM}$. Cultural medium was removed 24 hours later and the cells were washed with PBS solution. $\mathrm{DCFH}_{2}$-DA dye dissolved in PBS was applied to the cells at concentration of $25 \mathrm{mM}$ and incubated in $5 \% \mathrm{CO}_{2}$ for $30 \mathrm{~min}$ at $37^{\circ} \mathrm{C}$. Then the cells were washed once with PBS solution and irradiated for $30 \mathrm{~min}$ (ALKhT-ELOMED laser apparatus, $\lambda=670 \mathrm{~nm}$ ) at optical power of $8 \mathrm{~mW} / \mathrm{cm}^{2}$. Fluorescence intensity was measured with a TECAN SPARK 10M multi-functional spectrophotometer at $\lambda_{\text {ex }}=485 \mathrm{~nm}$ and $\lambda_{\text {em }}=535 \mathrm{~nm}$. Intracellular content of ROS with $\mathrm{DCFH}_{2}$-DA was determined in different time intervals (from 30 to $120 \mathrm{~min}$ ). A similar experiment was carried out as a control one in which no irradiation of cells was used. Relative intracellular content of ROS was calculated using MS Excel and Origin program packages.

\section{Microscopy}

Procedure for obtaining fluorescent micrographs is reported in. ${ }^{[18]}$ Accumulation of $\mathbf{I V}$ in cells was analyzed with an Axio Scope.A1 fluorescent microscope (Carl Zeiss, Germany) using A-Plan $40 \times / 0.65 \mathrm{Ph} 2$ and A-Plan $40 \times / 0.65$ M27 objectives. Samples were photographed using different sets of fluorescent filters, namely, Fs 49 DAPI (EX G 365, EM BP 445/50), Fs 45 HQ TexasRed (EX BP 560/40, EM BP).

\section{Results and Discussion}

Due to high solvability of DMSO which prevents $\pi-\pi$ interaction between Pcs molecules, the absorption spectrum of solution IV corresponds to the monomeric state of compound (Figure 2, spectrum 1). Almost no deviation from the Bouguer-Lambert-Beer law is observed for optical density values at low $(\mu \mathrm{M})$ concentration (see Electronic Supporting Information, ESI, Figure S1). The content of water of $\sim 14 \mathrm{v} / \mathrm{v} \%$ (DMSO $\left./ \mathrm{H}_{2} \mathrm{O}=6: 1\right)$ does not affect absorption spectra of monomer (Figure 2, spectrum 1), while further increase in medium polarity led to stacking aggregation of IV (spectrum 2).

\section{Compounds I-IV in Phosphate Buffer and Micellar Solutions of Cationic CTAB and CTPB}

Compounds I-IV are insoluble in water and transit into

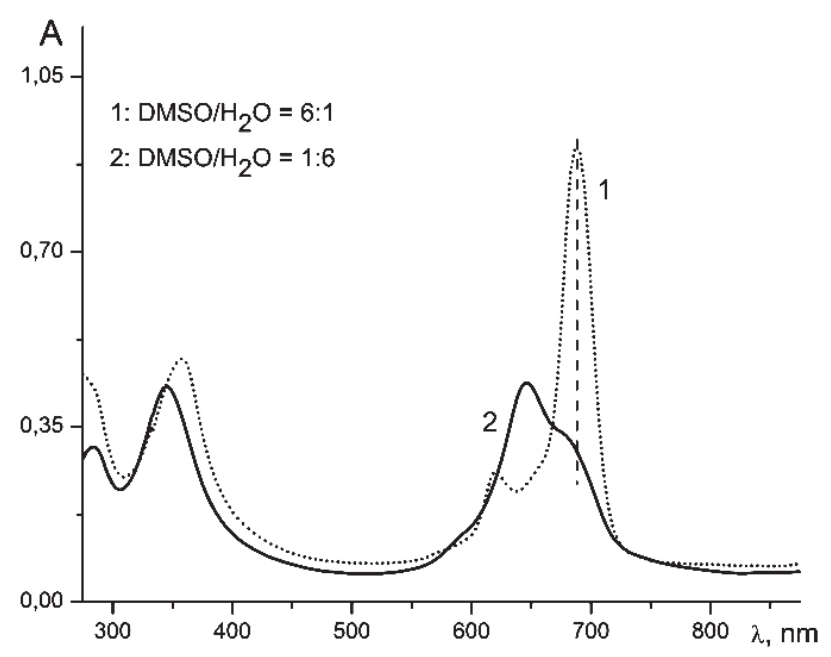

Figure 2. Absorption spectra for IV depending on a $\mathrm{DMSO} / \mathrm{H}_{2} \mathrm{O}$ ratio $(\mathrm{v} / \mathrm{v} \%)$. 
solution in phosphate buffer (PBS) with $\mathrm{pH}=7.4$ similarly to 1,5-bis[2-(oxyethoxyphosphoryl)-4-ethylphenoxy]-oxapentane. The latter is in solution with $\mathrm{pH}>7$ as dianion. ${ }^{[22]}$ As an example, the spectrum for compound III $\left(\mathrm{M}=2 \mathrm{H}^{+}\right.$, $\mathrm{R}^{\prime}=\mathrm{C}_{5} \mathrm{H}_{11}$ ) in PBS is shown in Figure 3. The maximum of its $Q$-band is in the range of absorption of $H$-dimers (spectrum 1, $\lambda_{\text {max }}=628 \mathrm{~nm}$ ) as well as compounds I and II. The absorption spectra for I-III in PBS remained almost unchanged upon long-term storage, and the alkyl group in the phosphoryl fragment did not affect shape and position of the $Q$-band of dimer.

Absorption spectra show that I-III are in monomer state in micellar solutions of cationic CTAB or CTPB $\{[$ surfactant $] \geq \mathrm{CMC}$ (critical micelle concentraction) $\}$ (see Figure 3, spectrum 3 for III, ESI Figure S2). For traditional cationic surfactants, spherical micelles are formed when their concentration in an aqueous solution is equal to approximately CMC. The values of $\mathrm{CMC}_{\mathrm{CTAB}}$ and $\mathrm{CMC}_{\mathrm{CTPB}}$ in water are $1.0 \cdot 10^{-3}$ and $0.16 \cdot 10^{-3} \mathrm{M}$, respectively, ${ }^{[23,24]} \mathrm{CMC}_{\mathrm{CTAB}}$ in PBS is $0.2 \cdot 10^{-3} \cdot{ }^{[25]}$ The lower is $\mathrm{CMC}$, the higher is stability of micelles.

Behaviour of compound IV is similar: it is a dimer in PBS (Figure 3, spectrum 2) and monomer with position and shape of the $Q$-band characteristic of metal PS in microheterogeneous medium (spectrum 4), respectively. A distinctive feature of the monomerization of compounds I-IV in a slightly alkaline medium is the high molar absorption coefficient \{for example, $\log \varepsilon_{686}=5.15$ (IV) and $\log \varepsilon_{710}$ $=5.37$ (III) $\}$ for $Q$-band. Polyvinylpyrrolidone does not affect the absorption spectra of monomer IV in system IV/CTAB/PBS.



Figure 3. Absorption spectra for III and IV in PBS before ( 1 and 2 ) and after ( 3 and 4 ) addition of CTAB ([CTAB] $\sim 5 \mathrm{CMC}$ ). Insert shows the view of spherical CTAB micelle.

Note that optical density of the $Q$-band of monomer IV $\left(A_{686}\right)$ increases with a $[\mathrm{CTPB}] /[\mathbf{I V}]$ ratio and attains maximum at $\sim 25$. This corresponds to $[\mathrm{CTPB}] \sim 1.55 \cdot 10^{-4}$ $\mathrm{M}$ (ESI, Figure S3) close to CMC..$^{[24]}$ According to ${ }^{[26]}$ critical micelle concentration, hydrodynamic micelle radius and aggregation number were $0.1 \mathrm{MM}, 2.1 \mathrm{~nm}$ and 29, respec- tively, for CTPB in $0.25 \mathrm{MM}$ aqueous solution. At [CTPB] $<$ $\mathrm{CMC}$ and $[\mathrm{CTPB}] /[\mathbf{I V}]<25$, the spectrum of monomeric Pc in CTPB solution changed in time indicating instability of a supramolecular ensemble.

\section{Compounds I-IV in the Presence of SDC}

Another interesting surfactant is biocompatible SDC. It turned out that the state of free metal I with four phosphoric acid groups in microheterogeneous polar medium depends on surfactant charge (Figure 4). Thus, compound I is mainly in aggregated form in solution of anionic SDC (spectrum 3), while in solution of cationic CTAB it is in monomeric form (Figure 4, spectrum 2). However, it should be noted that the presence of $\mathrm{SDC}$ in solution $([\mathrm{SDC}]>\mathrm{CMC})$ results in shift of the $Q$-band, which corresponds to $H$-aggregates and slight growth of optical density in the band range characteristic of metal free Pc monomer (spectra 1 and 3, respectively). Note that $\mathrm{H}_{2} \mathrm{cr}_{8} \mathrm{Pc}$ was also in aggregated state in microheterogeneous SDC medium. ${ }^{[27]}$

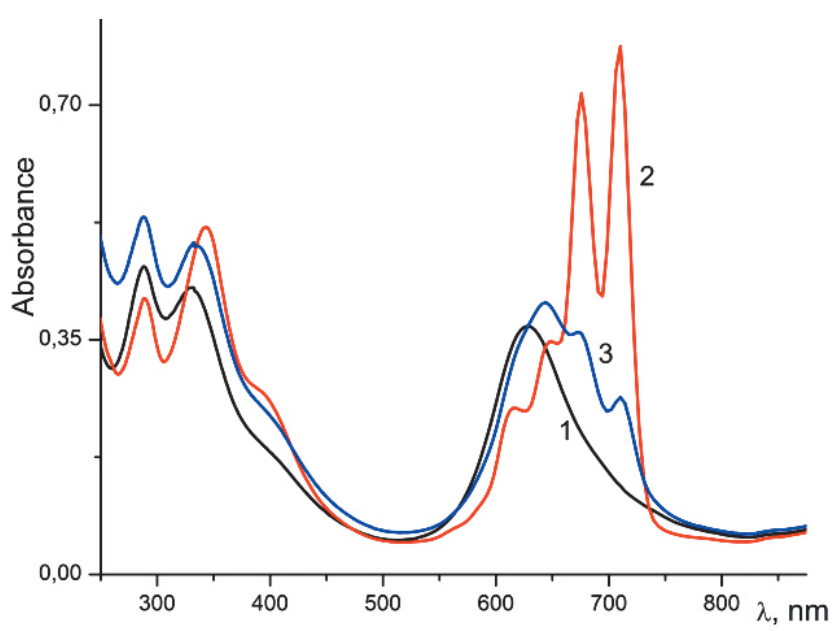

Figure 4. Absorption spectra for I/PBS (1), I/PBS/CTAB (2) and $\mathbf{I} / \mathrm{PBS} / \mathrm{SDC}$ (3).

Deconvolution of the absorption spectrum for the phthalocyanine III dimer in PBS using two Gauss functions $\left(\mathrm{R}^{2}=\right.$ 0.9993) suggests that at least two types of aggregates can be in solution. The addition of SDC to III/PBS solution ([SDC] $>\mathrm{CMC}$ ) leads to spectral changes (Figure 5, spectrum 3), and the spectrum is close to that for the III/CTAB/PBS system (Figure 3, spectrum 3), which can be considered as a four-component one $\left(\mathrm{R}^{2}=0.9972\right)$ with a $A_{647} / A_{618} \sim 1.3$ ratio for optical density of vibronic peaks. Absorption spectrum for III/PBS/SDC and its deconvolution $\left(\mathrm{R}^{2}=0.9995\right)$ by six Gaussian functions gives $A_{647} / A_{618} \sim 1.66$, that is evidence of the presence of $\sim 17 \%$ of metal-free Pc in aggregated state additionally to the monomeric form in the III/PBS/SDC system (ESI, Figures S4 and S5). Note that degree of monomerization of metal free Pcs I-III in micellar solutions of SDC decreases in the row $\mathrm{R}^{\prime}=$ pentyl $>$ ethyl $>$ H (Figure 5). The behavior of compound IV in micellar solutions of SDC in PBS phosphate buffer was previously discussed. ${ }^{[28]}$ 




Figure 5. Absorption spectra for microheterogeneous I/SDC, II/SDC/ and III/SDC systems in phosphate buffer. The insert shows a schematic representation of small aggregates (micelles) of SDC with a hydrophobic "pocket" formed with the participation of hydrophobic interactions.

\section{Photophysical Properties of III/CTAB/PBS and IV/SDC Systems}

Figure 6 shows the normalized absorption, excitation, and fluorescence spectra for the IV/SDC/PBS system. It can be seen that the excitation spectrum IV repeats the absorption spectrum, and the emission spectrum is bathochromically shifted relative to the absorption spectrum. The Stokes shift is of the order of $10 \mathrm{~nm}$ and lies in the region characteristic of other phthalocyanines in solution in monomeric form. ${ }^{[29]}$

The III/PBS system (Figure 3, spectrum 1) is inactive under excitation conditions $\left(\lambda_{\text {ex }}=625 \mathrm{~nm}\right): H$-dimers and larger aggregates show no fluorescence. ${ }^{[30]}$ Position of maximum in a fluorescence spectrum is independent of $\lambda_{\mathrm{ex}}$, and $I_{\mathrm{fl}}$ grows with $\lambda_{\mathrm{ex}}$ and degree of its overlap with

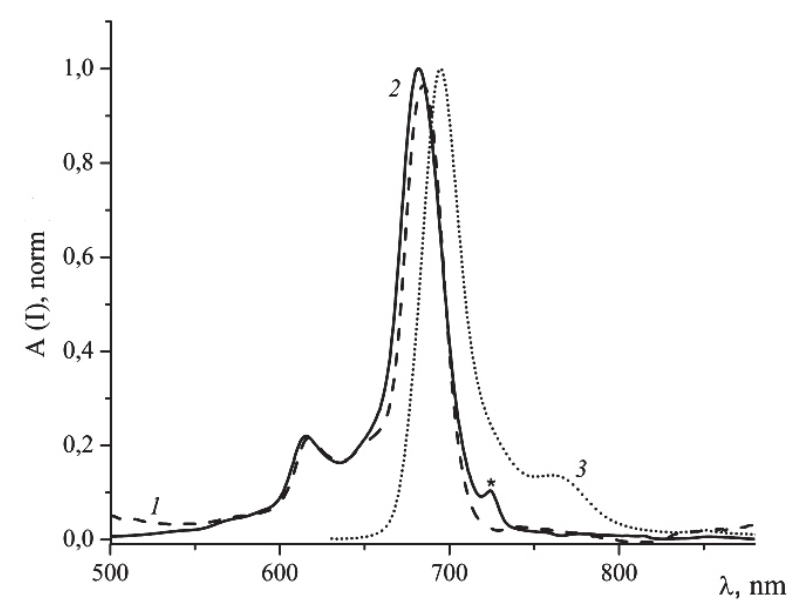

Figure 6. Normalized absorption, excitation $\left(\lambda_{\text {em }}=725 \mathrm{~nm}\right)$ and fluorescence $\left(\lambda_{\mathrm{ex}}=620 \mathrm{~nm}\right)$ for system IV $/$ SDC/PBS (1, 2, 3 , respectively). $[\mathbf{I V}]=1.3 \cdot 10^{-6} \mathrm{M}$ and $[\mathrm{SDC}]=13.4 \cdot 10^{-3} \mathrm{M}$. An asterisk denotes an artifact that occurs when phthalocyanine molecules are excited by light with $\lambda_{\text {em }}{ }^{[28]}$ absorption spectrum of III, respectively. The excitation spectrum corresponds to the absorption spectrum for III, and the Stokes shift is close to $8 \mathrm{~nm}$ (Figure 7). The registration of the fluorescence spectrum of III in micellar solutions of cationic CTAB and IV in micellar solution of anionic SDC confirms their monomolecular state and screening surfactant molecules in an aqueous environment, respectively.

\section{Photochemical Activity of III/CTAB/PBS and IV/CTAB/PBS Systems}

\subsection{Photostability}

In the dark, absorption spectra for the III/CTAB(CTPB)/ PBS and IV/CTAB(CTPB)/PBS remained unchanged within 2 weeks. When III/CTAB/PBS solution was irradiated by light $(\lambda=578 \mathrm{~nm})$ in the air, optical density of the sample decreased by $\sim 6 \%$ during 20 minutes. The rate of photodegradation of IV in microheterogeneous CTAB/PBS medium was higher. A similar result was obtained earlier for $\mathrm{H}_{2} \mathrm{cr}_{8} \mathrm{Pc}$ /sodium dodecyl sulfate and $\mathrm{Mgcr}_{8} \mathrm{Pc} /$ sodium dodecyl sulfate: metal free Pc was found to be more stable in micellar solutions under irradiation. ${ }^{[27]}$ Photobleaching of III and IV, and other Pc based systems ${ }^{[31-33]}$ was not accompanied by the appearance of new bands.

\subsection{Photochemical Reactions}

Among ROS generated under irradiation in the presence of Pcs in solution, singlet oxygen is now considered to be a major active (toxic) species. ${ }^{[34]}$ Singlet oxygen ${ }^{1} \mathrm{O}_{2}$ $\left({ }^{1} \Delta_{\mathrm{g}}\right)$ is a strong oxidizing agent for saturated C-H and unsaturated double bonds, sulfide, amino- and other electron donating groups in both organic and biomolecules. However, lifetime for ${ }^{1} \mathrm{O}_{2}$ in aqueous medium is shorter than 2 microseconds, ${ }^{[35]}$ i.e. by $1-2$ orders shorter than in other solvents. Since this hinders direct detection of the formation of ${ }^{1} \mathrm{O}_{2}$ in aqueous solution under irradiation, quantum



Figure 7. Excitation $\left(\lambda_{\mathrm{em}}=710 \mathrm{~nm}\right)$ and emission $\left(\lambda_{\mathrm{ex}}=650 \mathrm{~nm}\right)$ spectra for ${ }_{\text {III }} / \mathrm{CTAB} / \mathrm{PBS}$ system. 
efficiency $\varphi_{\Delta}$ of ${ }^{1} \mathrm{O}_{2}$ generation can be determined due to its photochemical reactions with various substrates.

In organic solvents, 1,3-diphenylisobenzofuran acts as a quencher of ${ }^{1} \mathrm{O}_{2}$, and in water, this function, along with other compounds of the anthracene series, is performed by 9,10-bis(dihydroxyphosphinylmethyl) anthracene (Figure 1). ${ }^{[12,36]}$ Anth $\mathrm{X}_{2}$ slowly dissolves in water to concentration $\sim 10^{-4} \mathrm{M}$ and well in PBS ( $\mathrm{pH}$ 7.4). The solvent (water or buffer solution), as well as the presence of a cationic surfactant does not affect the absorption spectrum of $A n t h X_{2}$. In the absence of light and at a temperature $\sim 5^{\circ} \mathrm{C}$, Anth $\mathrm{X}_{2} /$ surfactant solutions in water and PBS were stable for a sufficiently long time.

\subsubsection{Irradiation of 1,3-Diphenylisobenzofuran in DMSO in the Presence of IV}

Oxidation of 1,3-diphenylisobenzofuran in organic solvents in the presence of Pcs sensitizing photochemical reactions involving ${ }^{1} \mathrm{O}_{2}$ (PDT of the $2^{\text {nd }}$ type) is shown, for example, in. ${ }^{[37-39]}$ Photostability of PCs in solution is affected by both macrocycle charge and axial coordination of ligand with central ion of the macrocycle. ${ }^{[31]}$

As it was already mentioned above, IV in the DMSO solution is in monomeric form (Figure 2), which determines the ability of the Pc to generate ROS and sensitize the oxidation of DPBF, respectively. Solvent quality (for example, the presence of water) essentially affects the state of IV. In a DMSO solution, photobleaching of the PS becomes noticeable only with a high degree of oxidation of the quencher used. Photostability of monomer IV in DMSO allowed one to determine quantum yield of formation of ${ }^{1} \mathrm{O}_{2}$ in the presence of Pc as photosensitizer. Figure 8 shows changes in optical density of DPBF under irradiation in the presence of IV in DMSO. Kinetics of decrease in optical density of the peak with $\lambda_{\max }=417 \mathrm{~nm}$ characteristic of DPBF measured in the presence of PcZn (reference compound, $\Phi_{\Delta}{ }^{\mathrm{PcZn}}=0.67$ in $\mathrm{DMSO}^{[14]}$ ) and $\mathbf{I V}$, respectively, indicates higher photoactivity of PcZn as compared with the latter. The determined value of quantum yield of singlet oxygen for $\mathbf{I V}, \Phi_{\Delta}{ }^{\mathrm{IV}}$ is $0.48 \pm 0.05$.

\subsubsection{Oxidation of AnthX $X_{2}$ in Microheterogeneous Aqueous Medium of CTAB (CTPB)/PBS in the Presence of III or IV under Irradiation}

Surfactants affect photophysical and photochemical properties of organic molecules, in particular, spectralluminescent parameters and aggregation state of dyes change (see, for example, ${ }^{[40]}$ ). Figure ESI S6 shows spectral changes in solution of IV/AnthX $\mathrm{X}_{2} / \mathrm{CTAB}$ under irradiation of light with $670 \mathrm{~nm}$ wavelength positioned close to absorption maximum for monomer IV. It is seen that optical density of $\mathrm{AnthX}_{2}$ trap at $300-450 \mathrm{~nm}$ and the $Q$-band of monomer IV at $686 \mathrm{~nm}$ decreases in microheterogeneous medium (CTAB micelles), i.e. the effect of photoinduced ROS is accompanied by the formation of AnthX $\mathrm{X}_{2}$ peroxide (addition of ${ }^{1} \mathrm{O}_{2}$ in positions 9 and 10 of the anthracene molecule) and photodecomposition of IV. ${ }^{[4]}$ Time interval in which $A_{\text {mon }}{ }^{686}=$ const is almost absent.

Behaviour of Anth $\mathrm{X}_{2}$ in more stable microheterogeneous IV/CTPB system ${ }^{[42]}$ is shown in Figure 9. To estimate quantum yield of ${ }^{1} \mathrm{O}_{2}$ in microheterogeneous medium of cationic CTPB we used aqueous solution of methylene blue $(\mathrm{MB})$ at $\mathrm{p} H=7.4$. The $\Phi_{\Delta}{ }^{\mathrm{MB}}$ value is $(0.39 \pm 0.04) .^{[15]}$

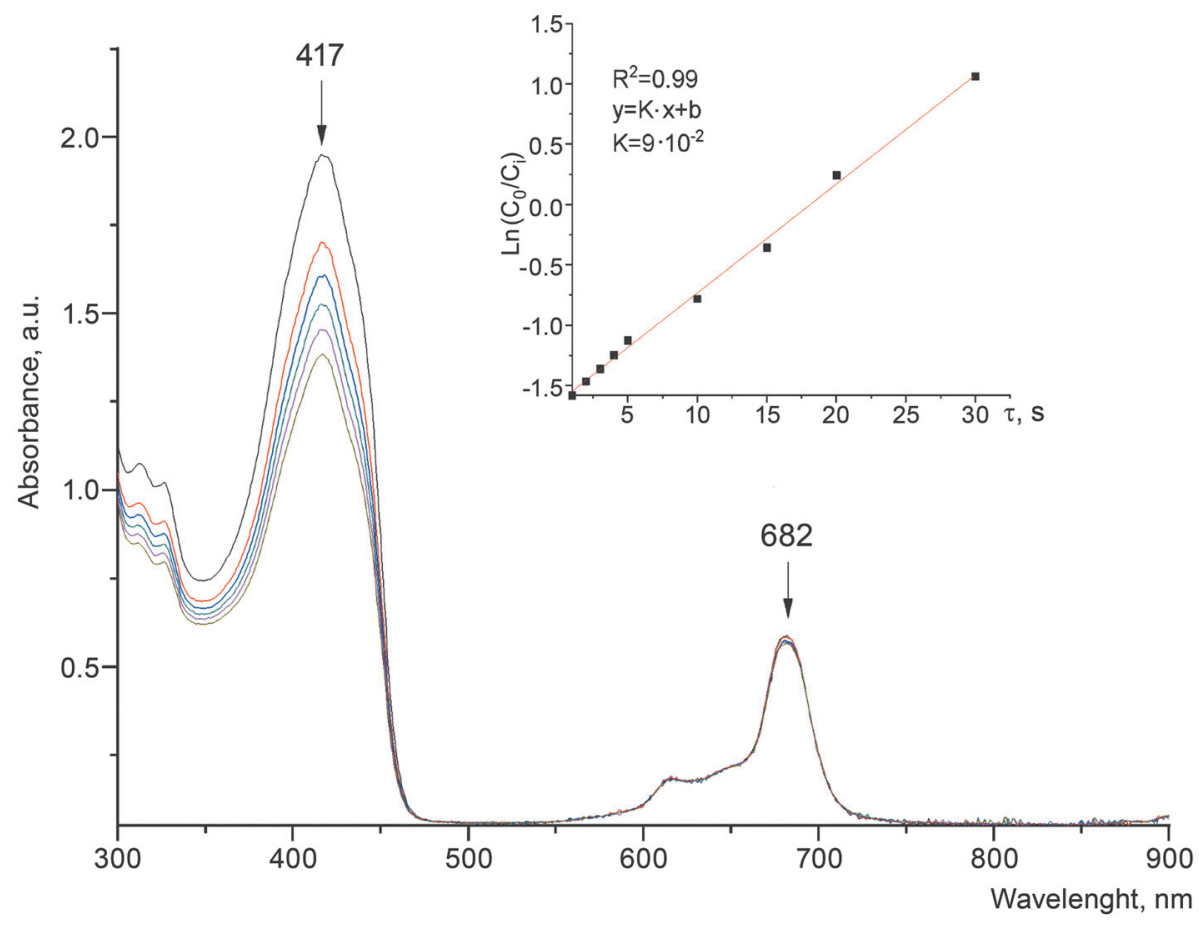

Figure 8. Changes in optical density (formation of ${ }^{1} \mathrm{O}_{2}$ ) in absorption range for quencher (DPBF) under laser irradiation in he presence of IV (DMSO, $670 \mathrm{~nm}$, irradiation time was 60 seconds). 
A

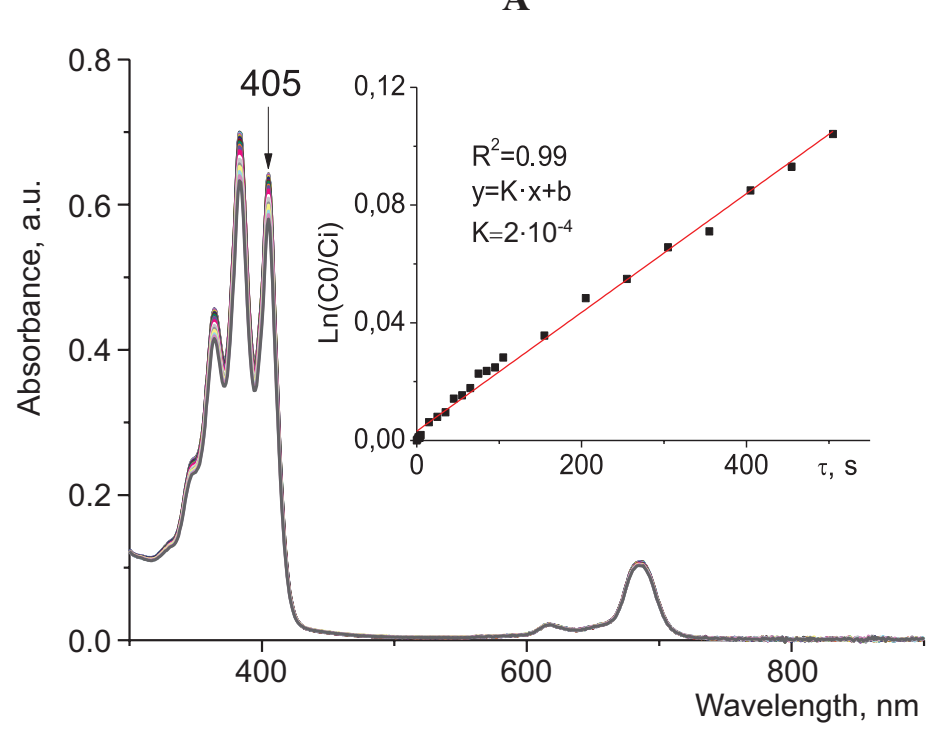

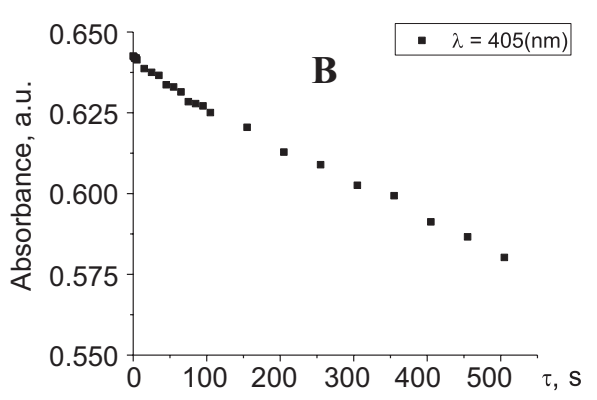

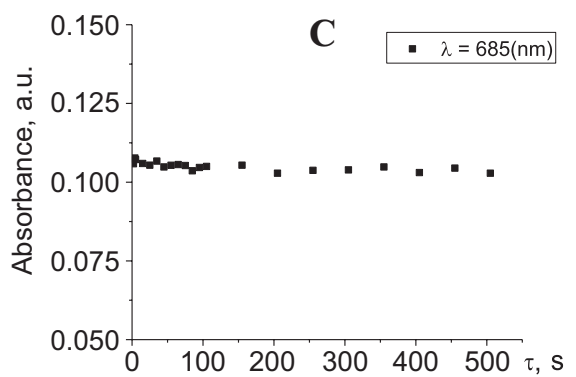

Figure 9. Changes in absorption spectra in IV/AnthX $/$ PBS under irradiation in microheterogeneous medium of cationic CTPB. Insert shows kinetics of photoinduced oxidation of $\mathrm{AnthX}_{2}(\mathrm{~A})$. Changes in optical density of AnthX $\mathrm{X}_{2}$ and $\mathbf{I V}$ in microheterogeneous medium of cationic CTPB in time (B and $\mathrm{C}$, respectively).

Besides, according to absorption spectra, IV is in monomeric form in both media (DMSO and CTPB micelles). Long wavelength maximum of the $Q$-band of this form is almost at the same wavelength. Thus, the estimated value of quantum yield of ${ }^{1} \mathrm{O}_{2}$ for $\mathbf{I V}$ in microheterogeneous aqueous medium was $0.54 \pm 0.05$, which is comparable with $\Phi_{\Delta}^{\text {IV }}$ in DMSO solution. This confirms the stability of monomeric state $\mathbf{I V}$ in micelles and retention of its ability to photodynamic action in media close to biological ones. It should also be noted that optical density in the $Q$-band range $(685 \mathrm{~nm})$ decreased by $\sim 15 \%$ after 30 min laser irradiation of $\mathrm{AnthX}_{2} / \mathbf{I V} / \mathrm{CTPB} / \mathrm{PBS}$, i.e. $\sim 85 \%$ of monomer IV remained in solution (Figure 9D). Photobleaching of $\mathrm{Zn}$ phthalocyaninate with menthol substituents in the macro-

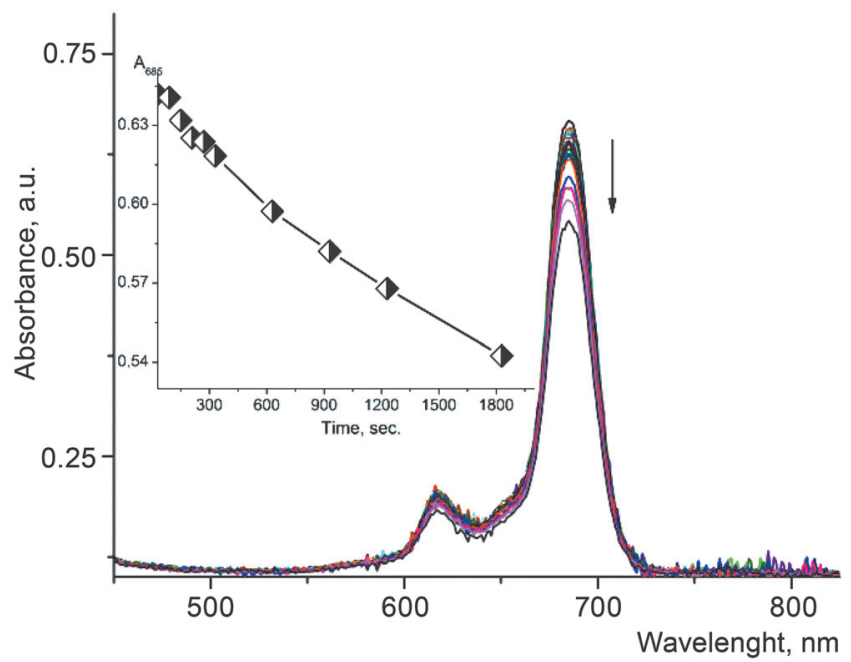

Figure 9D. Changes of absorption spectra in the IV/PBS/CTPB system in time under irradiation (laser, $\lambda=670 \mathrm{~nm}$ ). cycle (ZnMintPc) and simultaneous oxidation of ${ }^{1} \mathrm{O}_{2}$ trap in water-micellar solutions were reported, for example, in. ${ }^{[43]}$ Quantum yield of singlet oxygen for ZnMintPc depended on Pc state in microheterogeneous medium. ${ }^{[4]}$

The experimental data on supramolecular organization, photostability and formation of ${ }^{1} \mathrm{O}_{2}$ in the presence of $\mathbf{I V}$ in various media allowed us to investigate its photodynamic behaviour as a photosensitizer on HeLa cells. The first stage of our biological research involves the study of the uptake of the initial and previously unexplored IV by the cells $\mathrm{HeLa}$ (system IV/PBS), its dark and light toxicity, as well as the formation of reactive oxygen species in the presence of IV upon irradiation.

\section{Accumulation of IV in HeLa Cells}

One of components of culture medium is bovine serum albumin (BSA). Absorption spectra for IV in aqueous solution of BSA/PBS are close to those in EMEM (BSA $\sim 10 \%$ ) (Figure 10A, spectra 1 and 2) but are different from the spectrum for IV in pure PBS (spectrum 3). [BSA]/ [IV] molar ratio showed no noticeable effect on absorption spectra for IV. Absorption spectrum for IV/BSA/PBS solution can be considered as a sum of components including, along with aggregates of various compositions, apparently also some monomeric form of Pc (ESI, Figure 7). The difference in optical density values for solutions of IV before applying on cells and solutions measured after incubation was insignificant (Figure 10b). According to the absorption spectra (Figure 10), compound IV, like other Pcs (see, for example, $\left.{ }^{[45]}\right)$, binds to bovine serum albumin, but the presence of the latter shows no noticeable effect on the degree of IV accumulation by HeLa cells when applying. 

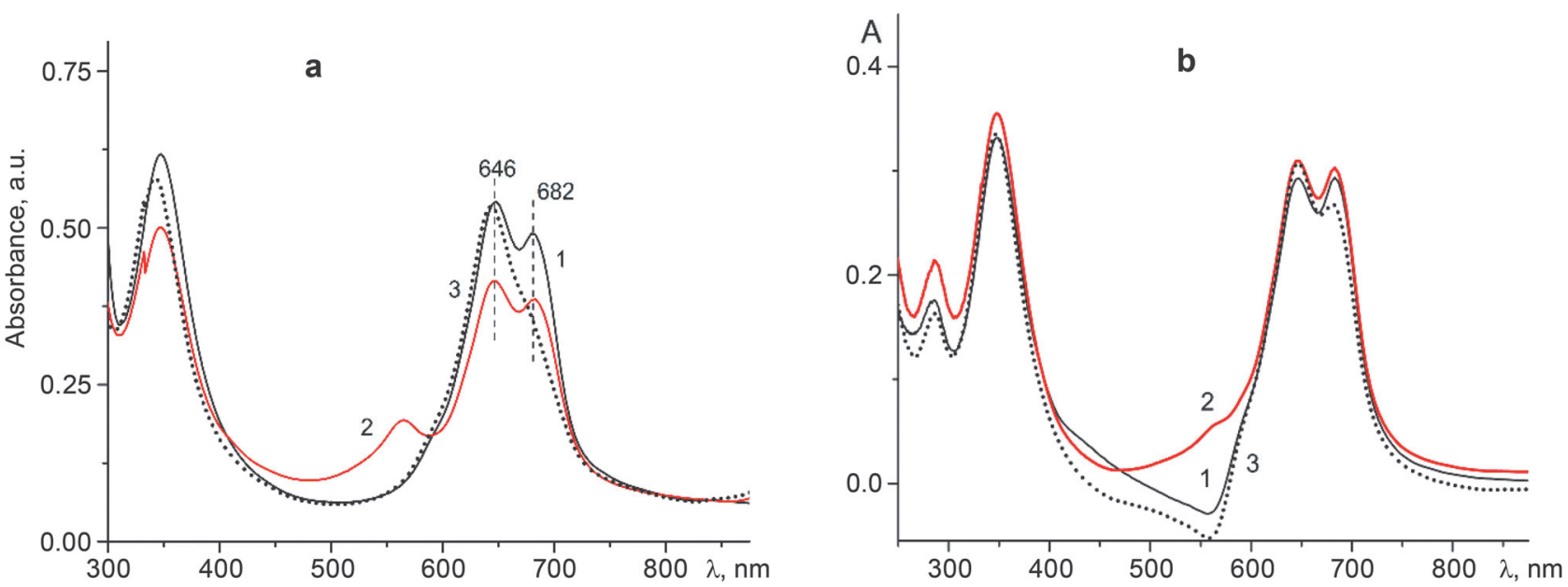

Figure 10. Absorption spectrum for IV in aqueous solution of BSA (1), aqueous solution in culture medium EMEM (2) and phosphate buffer (3) (a). Absorption spectrum for solutions taken from Vero (1) and Hela (2) cells after their incubation with IV (50 $\mu \mathrm{M})$ and absorption spectrum for IV (50 $\mu \mathrm{M} / \mathrm{EMEM}$ before incubation (3) (b).
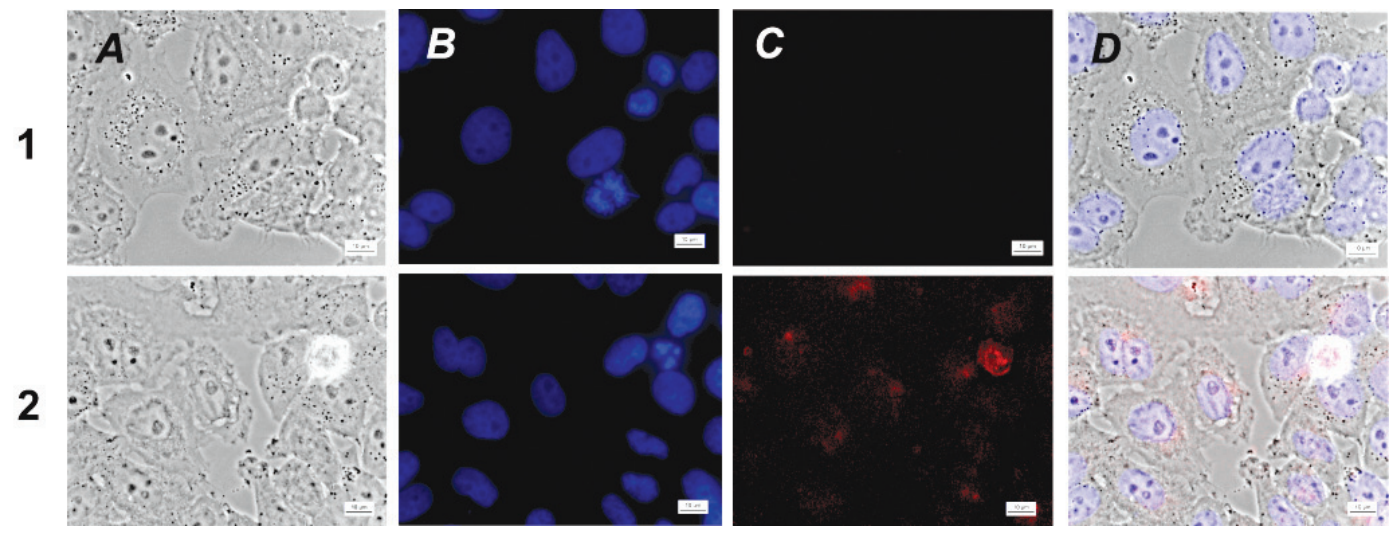

Figure 11. Micrographs of HeLa cells without IV (control) and in the presence of IV/SDC (panels 1 and 2, respectively). The cells were incubated with IV $(50 \mu \mathrm{M}) / \mathrm{SDC}(5 \mu \mathrm{M})$ in culture medium during 24 hours. $A$ - phase contrast, $B$ - nuclei stained with DAPI, $C-$ accumulation and localization of $\mathbf{I V}$, and $D$ - merger. Scale bar $10 \mu \mathrm{M}$.

Intracellular uptake and localization of IV was estimated by fluorescent microscopy. Note that accumulation of $\mathbf{I V}$ in cells was detected only upon introducing a small and nontoxic (in respect of cells) amount of SDC $(5 \mu \mathrm{M})$ in incubation medium. Phase contrast showed, firstly, that HeLa cell morphology is not violated upon incubation with solution of IV at an initial concentration of $50 \mu \mathrm{M}$ and $5 \mu \mathrm{M}$ of SDC during 24 hours (Figure 11, column A, panels 1 and 2). Secondly, well-observable red fluorescence, weak for $50 \mu \mathrm{M}$ of IV, (column C, panel 2) is evidence of accumulation of Pc by cells and its active fluorescent state. It should also be noted that cells incubated with $\mathbf{I V}$ were then repeatedly washed with warm PBS to fully remove unabsorbed Pc.

\section{Toxicity of $\mathbf{I V}$ and Determination of Intracellular Content of ROS under Irradiation}

Like other Zn-containing Pcs, ${ }^{[46]}$ IV shows no cytotoxicity in respect of HeLa cells at concentration of $0.195 \div 100$ $\mu \mathrm{M}$ without laser activation. Upon irradiation of cells in the presence of IV (diode laser, $670 \mathrm{~nm}$ ), light toxicity of IV $\left(\mathrm{IC}_{50}\right.$ dose) was 6.44 (Figure 12).

To estimate the formation and accumulation of ROS we used 2',7'-dichlorodihydrofluorescein diacetate ( $\left.\mathrm{DCFH}_{2}-\mathrm{DA}\right)$ dye, which hydrolyzes in the presence of intracellular esterases to form $\mathrm{DCFH}_{2}$. The later is oxidized by ROS to fluorescent 2',7'-dichlorofluorescein (DCF)..$^{[4]}$

Incubation of cells with solution of IV and further treatment by $\mathrm{DCFH}_{2}-\mathrm{DA}$ provides the formation and growth of ROS content under irradiation (photodynamic effect) as compared with control cells (Figure 13). Fluorescence intensity remained almost unchanged at $[\mathbf{I V}]=50 \mu \mathrm{M}$ and $100 \mu \mathrm{M}$. The values of $I_{\mathrm{fl}}^{\mathrm{DCF}}$, which can be evidence of the formation of ROS under irradiation, were relatively low even at such high concentrations of IV.

This can be due to low phototoxicity of IV and determination of intracellular content of ROS under irradiation level of accumulation of IV (see above) or its aggregated (nonfluorescent) state in cells. The shape of curves of $I_{\mathrm{fl}}^{\mathrm{DCF}} v s$ 


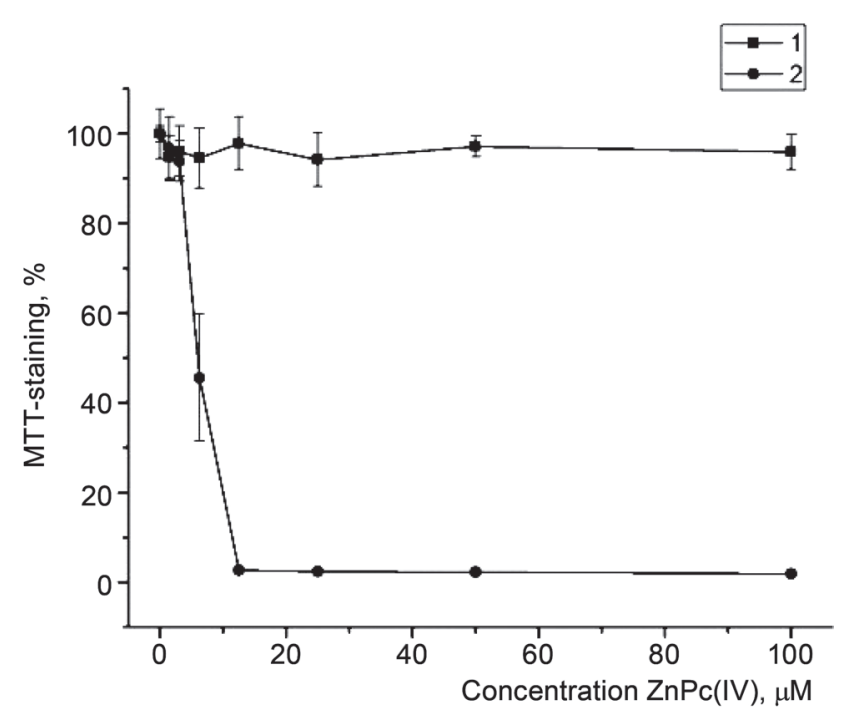

Figure 12. Dark and light toxicity of compound IV in HeLa cells depending on the concentration of PS in the incubation medium (black squares and circles, respectively).

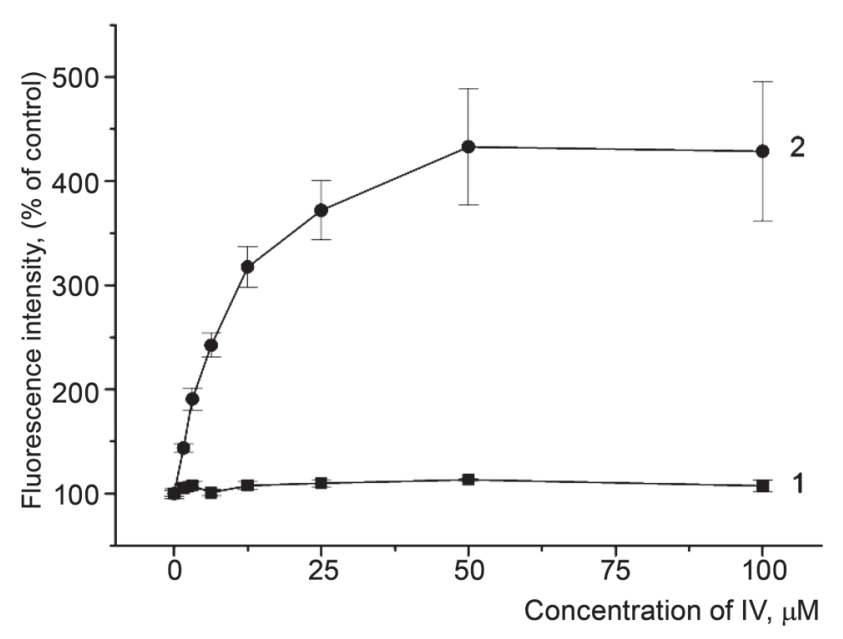

Figure 13. Changes in the DCF fluorescence intensity in HeLa cells in the presence of IV without irradiation (1) and under irradiation (2) at a concentration of 1.6 to $100 \mu \mathrm{M}$ in the incubation medium. Irradiation conditions: $\lambda=670 \mathrm{~nm}$, $8 \mathrm{~mW} / \mathrm{cm}^{2}, 30 \mathrm{~min}$.

time dependence is almost similar for irradiated and control cells (Figure 14) that is evidence of intracellular formation of ROS at selected concentrations of IV during irradiation and after exposure. This feature is characteristic of IV and is essentially different from the $I_{\mathrm{fl}}^{\mathrm{DCF}} v s$ time dependence obtained for HeLa cells in the presence of octa-crown containing $\mathrm{Mg}$ phthalocyaninate. ${ }^{[48]}$

From the one hand, the decrease in optical density of Anth $\mathrm{X}_{2}\left({ }^{1} \mathrm{O}_{2}\right.$ quencher $)$ indicates the formation of singlet oxygen in vitro in the presence of IV under irradiation (Figure 8 and 9). On the other hand, DCF intensity growth after switching off light indicates the formation of ROS after photodynamic effect (Figure 14).

One can suppose that in the presence of $\mathrm{DCFH}_{2}$ (ROS indicator) which is able to reduce the compounds with

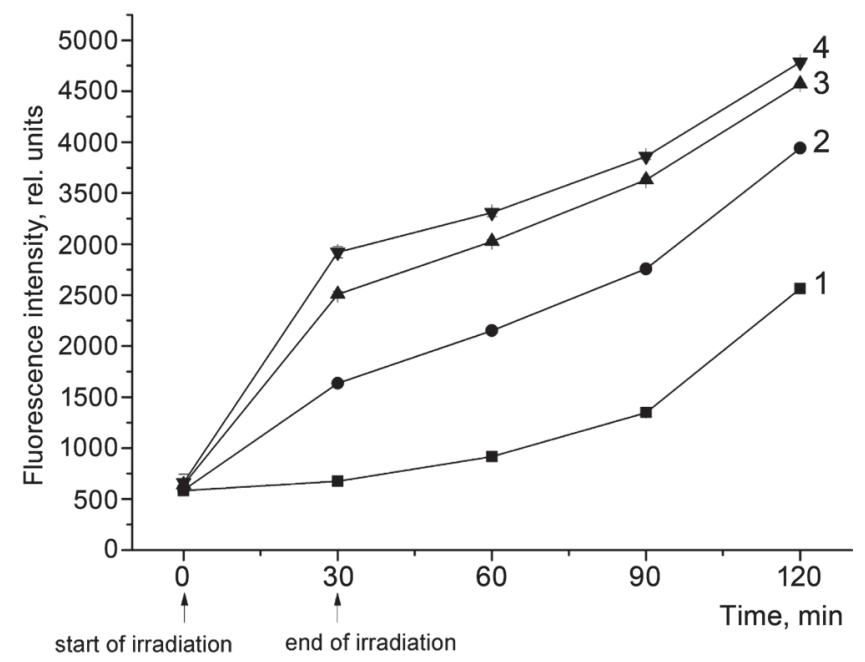

Figure 14. Photoinduced changes in fluorescence of $\mathrm{DCFH}_{2}-\mathrm{DA}$ detecting ROS in HeLa cells in control (1) and in the presence of IV at concentration of $6.2 \mu \mathrm{M}(2), 25 \mu \mathrm{M}$ (3) and $50 \mu \mathrm{M}$.

oxidation potentials lying in a wide potential range, ${ }^{[49]}$ the cells are still alive after photodynamic effect in the presence of IV accumulated by the cells in vitro, and retain ability to hydrolysis of $\mathrm{DCFH}_{2}-\mathrm{DA}$ and the formation of ROS similarly to control cells. This proves that ROS can apparently be produced in photodynamic process involving IV as photosensitizer with the participation of PDT reactions of both types (Scheme 1). The level of formation of intracellular ROS under irradiation in the presence of IV (see above) is in agreement with low accumulation of Pc and weak red fluorescence, respectively. This means that only a small amount of $\mathbf{I V}$ from the taken is absorbed by the cells during incubation.

\section{Discussion}

Supramolecular chemistry in water - non-covalent assembly of simple 'building' blocks to higher-level ordered structures - now attracts great attention. Conditions of solubilization and disaggregation of phosphoryl containing phthalocyanines and their metal complexes in aqueous medium accompanied by the formation of supramolecular ensembles were found based a supramolecular approach use of surfactants of different nature.

Sodium deoxycholate is a biocompatible micelle forming compound. Its properties are strongly different from those of conventional surfactants. SDC is specified by the ability to form primary aggregates (micelles) through hydrophobic interactions (Figure 5, insert), while hydrogen bonds are involved in the formation of large SDC aggregates (secondary micelles). ${ }^{[50]}$ Apparently, due to the solubilization of $\mathrm{R}^{\prime}$ in small hydrophobic cavities of SDC (Scheme 2), alkyl group of the $-\left(\mathrm{PO}(\mathrm{OH})\left(\mathrm{OR}^{\prime}\right)\right.$ fragment of macrocycle substituent provides monomerization of II and III by micelles (aggregates) of anionic SDC. Stability of such supramolecular ensemble is dependent on alkyl chain length (4.6 and $9.04 \AA$ for ethane and pentane, respectively) and its 
correspondence of linear size of SDC micelles: deoxycholic acid molecule length is $20-21 \AA$ from head to tail. Indeed, degree of monomerization of metal free I-III changes in the row: pentyl $>$ ethyl $>\mathrm{H}$. The state of $\mathbf{I V}$ in form of monomer in solutions of bile salts (sodium deoxycholate and others) was also proved by fluorescence spectroscopy. ${ }^{[28]}$

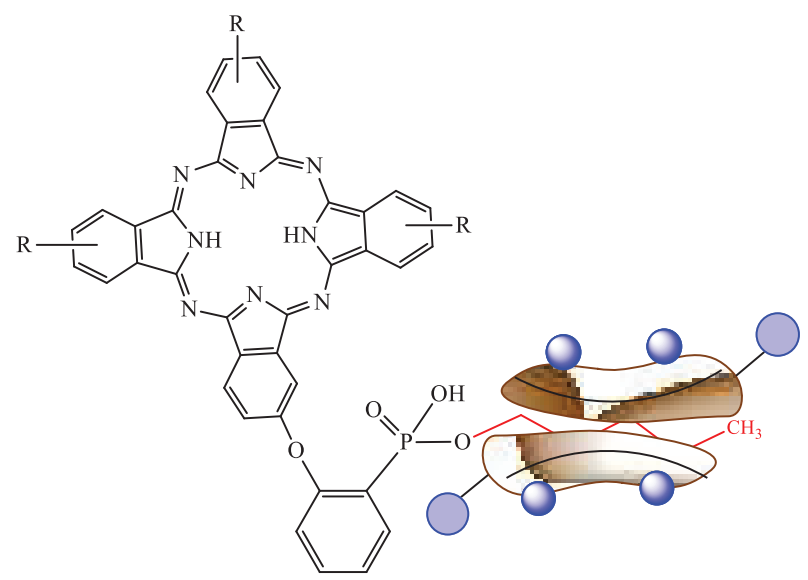

Scheme 2. Assumed encapsulation model for alkyl groups of phosphoryl fragment in substitutent in macrocycles of II and III by hydrophobic cavities of SDC. Solubilization of only one alkyl group is shown.

Compound IV is soluble in aqueous PBS and can carry up to four negative charges. The high hydrophilicity of the compound IV and the charge density, as well as the predominantly aggregated state of the Ps in the culture medium (Figure 10), may inhibit its penetration through the plasma membrane of HeLa cells and lead to the observed relatively low photodynamic activity. Thus, Photosens (hydroxyaluminium sulfophthalocyaninate with the number of sulfogroups $\sim 3.4$ ), a compound with a high degree of hydrophilicity, is distinguished by the slowest cell accumulation in vitro of transitional cell bladder cancer (T24) and human liver adenocarcinoma (SK-HEP-1). Its photodynamic activity was the lowest of the sequence of Ps - Photosens, Holosens and Phthalosens. ${ }^{[29]}$

Diphilicity of Ps has a decisive influence on their interaction with the bilayer. For example, the presence of a cholesterol fragment promotes the absorption of $\mathrm{ZnPc}$ molecules by the membrane and determines its position inside the membrane. ${ }^{[51]}$ Participation of $\mathrm{BS}$ in binding and delivery of drugs to biological targets is discussed, in particular, in. ${ }^{[52,53]}$ In our case, sodium deoxycholate was found also to be useful at absorption of IV by HeLa cells (see above).

Since Pcs and metal Pcs are used generally in aerobic conditions, their photostability is an important factor in PDT. It was shown in ${ }^{[31]}$ that photobleaching rate for both anionic and cationic $\mathrm{Zn}$ phthalocyaninates in aqueous solution is dependent on concentration of oxygen. Micellar membranes are able to create diffusion limitation for photochemical reactions at solubilization of Pcs in microheterogeneous medium. Diffusion of ${ }^{1} \mathrm{O}_{2}$ in micelles is lower than in solution ${ }^{[54]}$ that can provide its interaction with Pc and photodegradation of the latter.
Since each participant involved into the process can be in micelle, $\mathrm{O}_{2}$ transfer in sequence of micelle $\rightarrow$ volume $\rightarrow$ micelle (target), affects the rate of oxidation. ${ }^{[33]}$ Possible instability of Pc monomer in multi-component aqueous microheterogeneous medium under irradiation by light and participation of CTPB $(\mathrm{CTAB}) \sim \mathrm{Anth}_{2} \sim$ Pc fragments (particularly, $\mathrm{C}_{16} \mathrm{H}_{33}$-group of surfactant) in redox processes, which can be initiated by photogenerated ROS, are assumed to be important in view of photodegradation of Pc (PS) in microheterogeneous medium.

For the first time, zinc phthalocyaninate with phosphoryl groups in substituents of the macrocycle has been analyzed as potential photosensitizer in different media such as DMSO and microheterogeneous medium of cationic surfactant. The conditions for the formation of supramolecular ensembles in microheterogeneous media (cationic and anionic surfactants) with the predominant formation of Pc monomer as major product have been found. The state of IV as monomer in polar medium is preferable for fluorescent diagnostics and photodynamic therapy. Quantum yield of singlet oxygen for IV in DMSO (0.48 \pm $0.05)$ and microheterogeneous medium based on cationic CTPB $(0.54 \pm 0.05)$ is close to known values. ${ }^{[55-58]}$

Initial compound IV shows low cytotoxicity, high enough phototoxicity ( $\mathrm{IC}_{50}$ dose) and photostability, and participates as PS in the formation of intracellular ROS under irradiation in vitro. Thus, phosphoryl containing Pcs deserve further research including determination of quantum yield of fluorescence and lifetime of triplet state, and increase of degree of accumulation by cells as well as the SDC and CTPB effect on photodynamic activity.

\section{Conclusion}

Based on supramolecular approach, conditions for solubilization and disaggregation of phosphoryl containing phthalocyanines and their metal complexes in aqueous medium due to the formation of supramolecular ensembles have been found. Zinc phthalocyaninate IV with phosphoryl groups in substituents of the macrocycle has been analyzed for the first time as potential photosensitizer in different media. Supramolecular assembly of Pcs in solution, quantum yield of singlet oxygen $\Phi_{\Delta}^{\text {IV }}$ in DMSO and organized microheterogeneous medium based on cationic cetyltriphenylphosphonium bromide in combination with low cytotoxicity of $\mathbf{I V}$, high enough phototoxicity $\left(\mathrm{IC}_{50}\right.$ dose) and formation of intracellular active oxygen species in vitro at irradiation allow phosphoryl containing phthalocycanines and metal phthalocyanines to be considered as deserving further research as compounds useful in PDT.

Conflict of Interest. The authors declare no competing financial interest.

Acknowledgements. This work was financially supported by the Ministry of Education and Science of the Russian Federation (State Assignment, Project No. AAAA-A19119112590105-7 and AAAA-A19-119071890015-6), Russian Academy of Sciences (program No. 14.P) and partly RFBR (Grant No. 18-03-00743). 


\section{Notes and References}

1. Leznoff C.C., Lever A.P.B. Phthalocyanines: Properties and Applications (Leznoff C.C., Lever A.P.B., Eds.), New York: VCH, Vol. 1, 1989; Vol. 2, 1992; Vol. 3, 1993; Vol. 4, 1996.

2. Shaposhnikov G.P., Kulinich V.P., Mayzlish V.E. Modified Phthalocyanines and Their Structural Analogues. Moscow: Krasand, 2012. 480 p. (in Russ.) [Шапошников Г.П., Кулинич В.П., Майзлиш В.Е. Модифицированные фталоцианины и их структурные аналоги (Койфман О.И., ред.), М.: Красанд., 2012. 480 с.].

3. Wang S., Gao R., Zhou F., Selke M. J. Mater. Chem. 2004, 14, 487-493.

4. Lukyanets E.A. J. Porphyrins Phthalocyanines 1999, 3, 424-432.

5. Lukyanets E.A. Photodynamic Therapy and Photodiagnostics 2013, 2(3), 3-16 (in Russ.).

6. Yakubovskaya R.I., Plyutinskaya A.D., Luk'yanets Ye.A. Ross. Bioterapevt. Zh. [Russian Biotherapeutic Journal] 2014, 13, 65-72.

7. Yakubovskaya R.I., Morozova N.B., Pankratov A.A., Kazachkina N.I., Plyutinskaya A.D., Karmakova T.A., Andreeva T.N., Venediktova Yu.B., Plotnikova E.A., Nemtsova E.R., Sokolov V.V., Filonenko E.V., Chissov V.I., Kogan B.Ya., Butenin A.V., Feofanov A.V., Strakhovskaya M.G. Russ. J. Gen. Chem. 2015, 85, 217-239 [Ross. Khim. Zh. 2013, 57, 10-30 (in Russ.)].

8. Zhang X.-F., Xi Q., Zhao J. J. Mater. Chem. 2010, 20, 67266733 .

9. Lang K., Kubát P., Mosinger J., Wagnerová D.M. J. Photochem. Photobiol. A: Chem. 1998, 119, 47-52.

10. Goldshleger N.F., Shestakov A.F., Ovsyannikova E.V., Alpatova N.M. Russ. Chem. Rev. 2008, 77, 815-835.

11. Kalashnikova I.P., Baulin D.V., Baulin V.E., Tsivadze A.Yu. Russ. J. Gen. Chem. 2018, 88, 1510-1516.

12. Kuznetsova N.A., Gretsova N.S., Yuzhakova O.A., Negrimovskii V.M., Kaliya O.L., Luk'yanets E.A. Russ. J. Gen. Chem. 2001, 71, 36-41.

13. Seotsanyana-Mokhosi I., Kuznetsova N., Nyokong T. J. Photochem. Photobiol. A: Chem. 2001, 140, 215-222.

14. Kuznetsova N.A., Gretsova N.S., Kalmykova E.A., Makarova E.A., Dashkevich S.N., Negrimovskii V.M., Kaliya O.L., Luk'yanets E.A. Russ. J. Gen. Chem. 2000, 70, 133-141.

15. Blum A., Grossweiner L.I. Photochem. Photobiol. 1985, 41, 27-32.

16. Experimental Methods of High Energy Chemistry (Melnikov M.Y., Ed.), Moscow: MGU Publishing House, 2009. 824 p. [Экспериментальные методы химии высоких энергий (Мельников М.Я., ред.), М.: Изд-во МГУ, 2009. 824 с.].

17. Sassoon R.E., Gershuni S., Rabani J. J. Phys. Chem. 1985, 89, 1937-1945.

18. Lapshina M.A., Norko S.I., Baulin V.E., Terentiev A.A., Tsivadze A.Yu., Goldshleger N.F. Macroheterocycles 2018, 11, 396-403.

19. Mosmann T. J. Immunological Methods 1983, 65, 55-63.

20. Chou T.C., Talalay P. Adv. Enzyme Regul. 1984, 22, 27-55.

21. Chou T.C. Pharm. Rev. 2006, 58, 621-681.

22. Baulin V.E., Tsebrikova G.S., Baulin D.V., Al Ansary Biomed. Chem.: Res. Methods 2018, 1, e00043.

23. Tedeschi A.M., Franco L., Ruzzi M., Paduano L., Corvaja C., D' Errico G. Phys. Chem. Chem. Phys. 2003, 5, 4204-4209.

24. Verma S.K., Ghosh K.K. J. Surfact. Deterg. 2011, 14, 347-352.

25. Bahri M.A., Hoebeke M., Grammenos A., Delanaye L., Vandewalle N., Seret A. Colloids Surf., A 2006, 290, 206-212.

26. Vagapova G.I., Valeeva F.G., Gainanova G.A., Syakaev V.V., Galkina I.V., Zakharova L.Ya., Latypov S.K., Konovalov A.I.
Colloids Surf., A: Physicochem. Engineering Aspects 2013, 419, 186-193.

27. Goldschleger N.F., Gak V.Yu., Kalashnikova I.P., Baulin V.E., Ivanchikhina A.V., Smirnov V.A., Shiryaev A.A., Tsivadze A.Yu. Prot. Met. Phys. Chem. Surf. 2018, 54, 1092-1101.

28. Goldshleger N.F., Gak V.Yu., Lapshina M.A., Baulin V.E., Shiryaev A.A., Tsivadze A.Yu. Russ. Chem. Bull. Intern. Ed. 2018, 67, 2205.

29. Brilkina A.A., Dubasova L.V., Sergeeva E.A., Popelov A.J., Shilyagina N.Y., Shakhova N.M., Balalaeva I.V. J. Photochem. Photobiol., B: Biology 2019, 191, 128-134.

30. Kasha M., Rawis H.R., El-Bayoumi M.A. Pure Appl. Chem. 1965, 11, 371.

31. Kuznetsova N.A., Makarov D.A., Yuzhakova O.A., Solovieva L.I., Kaliya O.L. J. Porphyrins Phthalocyanines 2010, 14, 968-974.

32. Komissarov A.N., Makarov D.A., Yuzhakova O.A., Savvina L.P., Kuznetsova N.A., Kaliya O.L., Lukyanets E.A., Negrimovsky V.M. Macroheterocycles 2012, 5, 169-174.

33. Lastovoy A.P., Kuznetsova N.A., Slivka L.K., Makarova E.A. J. Porphyrins Phthalocyanines 2014, 18, 457-464.

34. Sharman B.M., Allen C.M., van Lier J.E. Methods Enzymol. 2000, 319, 376-400.

35. Einführung in die Photochemie (Becker H.O., Ed.) Berlin: Wissenschaften, 1976.

36. The ${ }^{1} \Delta_{\mathrm{g}}$ state is characterized by reactions of coordinated addition, in which the $\mathrm{O}_{2}$ molecule combines with the molecules of the reagents, forming a cyclic peroxide, which is accompanied by changes in absorption spectra.

37. Lapkina L.A., Gorbunova Yu.G., Gil D.O., Ivanov V.K., Konstantinov N.Yu., Tsivadze A.Yu. J. Porphyrins Phthalocyanines 2013, 17, 564-572.

38. Spiller W., Kliesch H., Wöhrle D., Hackbarth S., Röder B., Schnurpfeil G. J. Porphyrins Phthalocyanines 1998, 2, $145-158$.

39. Matlou G.G., Oluwole D.O., Prinsloo E., Nyokong T. J. Photochem. Photobiol. B: Biology 2018, 186, 216-224.

40. Solotareva Yu.O., Farrakhova D.S., Kupriyanova E.N., Loshchenov V.B. Biomed. Photonics 2018, 7, 4-20.

41. Photobleaching of dye is accompanied by decrease of optical density of Pc under irradiation and is a result of chromophore decay to weakly colored fragments absorbing light in UV range.

42. Unirradiated solution of IV remained almost unchanged in microheterogeneous medium of CTAB for a long time. For example, the value of optical density in the $Q$-band range for monomer IV was decreased by $\sim 10 \%$ during 2.5 months. However, in the presence of Anth $\mathrm{X}_{2}$, fast enough decrease of optical density in time was observed for both components (trap and PS).

43. Romero M.P., Gobo N.R.S., de Oliveira K.T., Iamamoto Y., Serra O.A., Louro S.R.W. J. Photochem. Photobiol. A: Chemistry 2013, 253, 22-29.

44. The values of quantum yield $\Phi_{\Delta}{ }^{1} \mathrm{O}_{2}$ for $\mathrm{ZnMintPc}$ were 0.51 (DMF), 0.001 (SDC micelles), 0.020 (CTAB micelles), 0.091 (Twin 80 micelles) and $\sim 1$ (pluronic F127 micelles). Microheterogeneous medium: surfactant/ZnMintPc in DMF $(45 \mu \mathrm{L})$ was added to PBS $(10 \mathrm{mM}, 3 \mathrm{~mL}), \mathrm{ZnPc}\left(\Phi_{\Delta}=0.56\right.$, $\mathrm{DMF}$ ) was used as a reference compound in both media (DMF and micelles).

45. Kollar J., Machacek M., Jancarova A., Kubat P., Kucera R., Miletin M., Novakova V., Zimcik P. Dyes Pigm. 2019, 162, 358-366.

46. Manilova B., Binder S., Malina L., Jiravova J., Langova K., Koralova H. Anticancer Res. 2015, 35, 3943-3952.

47. Chen X., Zhong Z., Xu Z., Chen L., Wang Y. Free Radical Res. 2010, 44, 587-604. 
48. Lapshina M., Ustyugov A., Baulin V., Terentiev A., Tsivadze A., Goldshleger N. J. Photochem. Photobiol. B: Biology 2020, 202, article 111722.

49. Reiniers M.J., van Golen R.F., Bonnet S., Broekgaarden M., van Gulik T.M., Egmond M.R., Heger M. Anal. Chem. 2017, 89, 3853-3857.

50. Goldshleger N.F., Lobach A.S., Baulin V.E., Tsivadze A.Yu. Russ. Chem. Rev. 2017, 86, 269-297.

51. Huang Y., Liu Y., Chen Y., Song M., Huang MXue, J. Liu L., Li J. J. Porphyrins Phthalocyanines 2018, 22, 1-7.

52. Holm R., Mullertz A., Mu H. Int. J. Pharm. 2013, 453, 44-55.

53. Stojančević M., Pavlović N., Goločorbin-Kon S., Mikov M., Front. Life Sci. 2013, 7, 112-122.
54. Ozog L., Aebisher D. Eur. J. Clin. Exp. Med. 2018, 16, 123-126.

55. Davila J., Harriman A. Photochem. Photobiol. 1990, 51, 9-19.

56. Vilsinski B.H., Witt M.A., Barbosa P.M., Montanha M.C., Nunes C.S., Bellettini I.C., de Castro L.V., Sato F., Baesso M.L., Muniz E.C., Caetano W. J. Mol. Liq. 2018, 271, 949-958.

57. Siqueira-Moura M.P., Primo F.L., Espreafico E.M., Tedesco A.C. Mater. Sci. Eng.: C 2013, 33, 1744-1752.

58. $\Phi_{\Delta}^{\mathrm{ZnPcl}} \mathrm{O}_{2}=0.56$ (DMF), Aluminum phthalocyanine trisulfonate and zinc phthalocyanine trisulfonate : $\Phi_{\Delta}{ }^{1} \mathrm{O}_{2}{ }^{\mathrm{AlPcS}}=0.34$ and $\Phi_{\Delta}{ }^{1} \mathrm{O}_{2}{ }^{\mathrm{ZnPSS}}=0.36\left(2 \cdot 10^{-3} \mathrm{M} \mathrm{PBS}, 1.0 \mathrm{w} / \mathrm{w} \% \mathrm{NaCl}\right)$, Aluminum phthalocyanine chloride $\Phi_{\Delta}{ }^{1} \mathrm{O}_{2}=0.3$ (diblock copolymer micelle), Aluminum phthalocyanine chloride $\Phi_{\Delta}{ }^{1} \mathrm{O}_{2}{ }^{\text {ClAlPc }}=0.8$ (polymeric nanocapsule). 